University of Nebraska - Lincoln

DigitalCommons@University of Nebraska - Lincoln

Faculty Publications from the Harold W. Manter Laboratory of Parasitology

4-1983

Evaluation of the Status of Texanocotyle pogoniae and

Laterocotyle padreinsulae (Trematoda: Aspidogastridae)

Sherman S. Hendrix

Gettysburg College

Robin M. Overstreet

Gulf Coast Research Laboratory, robin.overstreet@usm.edu

Follow this and additional works at: https://digitalcommons.unl.edu/parasitologyfacpubs

Part of the Parasitology Commons

Hendrix, Sherman S. and Overstreet, Robin M., "Evaluation of the Status of Texanocotyle pogoniae and Laterocotyle padreinsulae (Trematoda: Aspidogastridae)" (1983). Faculty Publications from the Harold W. Manter Laboratory of Parasitology. 307.

https://digitalcommons.unl.edu/parasitologyfacpubs/307

This Article is brought to you for free and open access by the Parasitology, Harold W. Manter Laboratory of at DigitalCommons@University of Nebraska - Lincoln. It has been accepted for inclusion in Faculty Publications from the Harold W. Manter Laboratory of Parasitology by an authorized administrator of DigitalCommons@University of Nebraska - Lincoln. 
J. Parasitol., 69(2), 1983, pp. 431-432

(C) American Society of Parasitologists 1983

\section{Evaluation of the Status of Texanocotyle pogoniae and Laterocotyle padreinsulae (Trematoda: Aspidogastridae)}

Sherman S. Hendrix, Department of Biology, Gettysburg College, Gettysburg, Pennsylvania 17325; and Robin M. Overstreet, Gulf Coast Research Laboratory, Ocean Springs, Mississippi 39564

Simpson and McGraw (1979, Southwest. Nat. 24: 557-562) erected two genera for two new species of aspidogastrid trematodes infecting the black drum, Pogonias cromis (Linnaeus), along the Texan Gulf of Mexico coast. Examination of holotypes and paratypes of each reveals that the two species have been described previously and that the genera are invalid.

We consider Texanocotyle pogoniae Simpson and McGraw, 1979 a subjective junior synonym of Cotylogaster basiri Siddiqi and Cable, 1960. Therefore, Texanocotyle Simpson and McGraw, 1979 becomes a junior synonym of Cotylogaster Monticelli, 1892. Simpson and McGraw (1979, loc. cit.) based their generic determination primarily on the presence of tubular, rather than follicular, vitellaria. Whereas the holotype (USNM Helm. Coll. No. 76461) appeared poorly fixed, some follicles were clearly present. The examined paratypes (USNM Helm. Coll. No. 76462; Lamar University PC 1701 I-1 and PC 1726 I-4) showed them more clearly in a narrow inverted U-shaped form unlike that in their illustration. A true cirrus sac was lacking as discussed in a redescription of $C$. basiri by Hendrix and Overstreet (1977, J. Parasitol. 63: 810-817). Additionally, pigmented eyespots occurred in Simpson and McGraw's specimens even though dispersed in some individuals. Simpson and McGraw had mature specimens and in the two paratypes from Lamar, well-developed embryos in utero each had two eyespots. Although difficult to determine in the examined specimens and not mentioned in their description, the number of peripheral alveoli appeared to range from 46 to 58 . Cotylogaster basiri is now known from Puerto Rico (Siddiqi and Cable, 1960, Sci. Surv. Porto Rico and Virgin Islands 17: 257-369), Jamaica (Nahhas and Cable, 1964, Tulane Stud. Zool. Bot. 11: 169-228), Mississippi, Louisiana (Hendrix and Overstreet, 1977, loc. cit.), and Texas (Simpson and McGraw, 1979, loc. cit.), with Pogonias cromis as one of its hosts. We have collected specimens from $P$. cromis in Mississippi also.

Laterocotyle padreinsulae Simpson and McGraw, 1979 agrees in all aspects with and is considered a subjective junior synonym of Cotylogaster dinosoides Hendrix and Overstreet, 1977, making Laterocotyle Simpson and McGraw, 1979 a junior synonym of Cotylogaster. Simpson and McGraw described $L$. padreinsulae as having marginal alveoli directed laterally rather than ventrally and having one rather than two testes. Based on the holotype (USNM Helm. Coll. No. 76463) and paratypes (USNM Helm. Coll. No. 76464; Lamar University PC 1720 I-4 and PC 1726 I-1), the alveoli, numbering 39 to 42 when counting those at the anterior margin, faced the same as in specimens from Mississippi and the worms had two testes. Specimens were not well developed, and perhaps Simpson and McGraw mistook the anterior testis for the ovary because in some specimens it partially obscured the ovary. The holotype from Texas had poorly-developed eggs reaching as large as 56 by $29 \mu \mathrm{m}$. Three additional specimens from the intestine of the drum in Mississippi 
with a ventral holdfast 3.0 to $5.6 \mathrm{~mm}$ long had eggs 62 to $96 \mu \mathrm{m}$ long by 33 to $39 \mu \mathrm{m}$ wide. Testicular length in those specimens was 53 to $1,024 \mu \mathrm{m}$. Because mature individuals infect the black drum, that fish can be considered a true definitive host as well as the only known vertebrate host.
We thank Drs. J. Leon McGraw, Jr. and Ralph Lichtenfels for loaning us specimens. This study was conducted in cooperation with the U.S. Department of Commerce, NOAA, National Marine Fisheries Service, under PL 88-309, Project No. 2-382-R. 